$10-7-2011$

\title{
Viewing the public sphere with influentials and citizens
}

Leo Wayne Jeffres

Cleveland State University, I.jeffres@csuohio.edu

Guowei Jian

Cleveland State University, g.jian@csuohio.edu

Jae-Won Lee

Cleveland State University

C. Ellen Connally

Josie El Seikali

Cleveland State University

Follow this and additional works at: https://engagedscholarship.csuohio.edu/clcom_facpub

Part of the Civic and Community Engagement Commons, and the Social Influence and Political Communication Commons

How does access to this work benefit you? Let us know!

\section{Publisher's Statement}

This is an Author's Accepted Manuscript of an article published in Qualitative Research Reports in Communication 10-07-2011, available online: http://www.tandfonline.com/10.1080/

17459435.2011 .601526

\section{Recommended Citation}

Jeffres, L. W., Jian, G., Lee, J., Connally, C. E., \& Seikali, J. E. (2011). Viewing the public sphere with influential and citizens. Qualitative Research Reports in Communication, 12(1), 60-70. doi:10.1080/ 17459435.2011 .601526

This Article is brought to you for free and open access by the School of Communication at EngagedScholarship@CSU. It has been accepted for inclusion in Communication Faculty Publications by an authorized administrator of EngagedScholarship@CSU. For more information, please contact library.es@csuohio.edu. 


\title{
Viewing the Public Sphere With Influentials and Citizens
}

\author{
Leo W. Jeffres, Guowei Jian, Jae-won Lee, \\ C. Ellen Connally, \& Josie El Seikali
}

The currently popular emphasis on democratic discussion in the "public sphere" often is critically viewed by observers commenting on issues of participation, empowerment, and efficacy without input from influentials, whose voices often are the content of public debates. Habermas was critical of the quality of democratic discourse, arguing for an "ideal speech situation" where participants are free to question all proposals; introduce proposals; and express their attitudes, wishes, and needs. This article examines perceptions of the climate of communication in the public sphere by influentials and the general public of a major urban area.

Keywords: Community Dialogue; Elites/Influentials; Public Sphere

The currently popular emphasis on democratic discussion in the "public sphere" often is critically viewed by observers commenting on issues of participation, empowerment, and efficacy without input from influential citizens, or elites, whose voices often are the content of public debates. Habermas (1990) was critical of the quality of democratic discourse, arguing for an "ideal speech situation" where participants are free to question all proposals; introduce proposals; and express their attitudes, wishes, and needs (pp. 88-89). Leaning on Marxist criticism and the constraints of corporate

Leo W. Jeffres (PhD, University of Minnesota, 1976) is a professor in the School of Communication, Cleveland State University, 2121 Euclid Ave., Cleveland, OH 44115. E-mail: 1.jeffres@csuohio.edu. Guowei Jian (PhD, University of Colorado, 2003) is an associate professor in the School of Communication, Cleveland State University, 2121 Euclid Ave., Cleveland, OH 44115. E-mail: g.jian@csuohio.edu. Jae-won Lee (PhD, University of Iowa, 1972) is professor emeritus in the School of Communication, Cleveland State University, 2121 Euclid Ave., Cleveland, OH 44115. E-mail: j.lee@csuohio.edu. C. Ellen Connally (Master and Juris Doctorate, Cleveland State University, and $\mathrm{PhD}$ Candidate, University of Akron) is President of the Cuyahoga County Council. E-mail: ceconnally@cuyahogacounty.us. Josie El Seikali (MA, Cleveland State University, 2007) (was a member of the project team). 
media ownership, researchers mining this vein stress the materialistic-control aspects of ownership and presume to lecture what should be done to wrestle control into the hands of intellectuals. Whereas a Habermas (1990) approach suggests elites operate with a more singular voice to stymie input by social groups, particularly when economic interests are at stake, the more enduring issues in communities today include problems of race, ethnicity, and education, where solutions are less easily framed in terms of status and access to the channels of communication. Habermas (1998) also was more concerned with political elites than those with other bases of power in society; thus, we need to examine a broader range of voices contributing to the public sphere in communities.

Beyond the critical scholarship, another literature focusing on social constraints is found in the pluralism perspective that is the basis of work by Tichenor, Donohue, and Olien (1980) and others examining community constraints on media performance. That perspective sees media in particular as operating to support vested interests but with more inclusive and diverse messages in heterogeneous communities where getting conflict out in the open is more functional. Thus, this view would suggest that there is not an "ideal speech situation," but rather, its nature changes to fit the community context.

In both literatures, the focus is on how power is exercised by the most influencial citizens of a community, often referred to as elites, to the detriment of a more democratic dialogue and more inclusive participation by the public. ${ }^{1}$ Although the notion of the "public sphere" has generated an enormous literature, it risks becoming an empty metaphor wherein political and academic interests advance ideological positions unless we place some boundaries on the concept. For communication scholars, the public sphere refers to the "turf" occupied by more familiar terms such as public discourse, public communication, and public debate, as well as related concepts of public opinion and the climate for communication. It is separate from private views and conversations, and it is observed in public forums and public media.

These perspectives paint a static view of how power is exercised and ignore the constraints that operate in the public arena to shape communication not just among the general public, but among influentials as well. This is supported by a study that found community economic structural factors central to Habermas (1990) and the pluralistic perspective were less important than ethnic/religious diversity as constraints on community media (Jeffres, Cutietta, Sekerka, \& Lee, 2000). Scott (2007) recognized this potential source of power.

Before discussing the quality of public discussion, we return to some earlier views of power in political science and sociology. ${ }^{2}$ The elitist model explains power as a natural function of status in communities (e.g., Lynd \& Lynd, 1929, 1937; Wright Mills, 1956), but fails to explain why elites survive despite fierce internal conflicts. Mass theories of power primarily focus on the led rather than the leaders, and stress alienation and apathy (e.g., Vidich \& Bensman, 1960). Pluralistic theories recognize the pluralist nature of contemporary American political life, and focus on the channels and techniques through which community leaders achieve consensus in decision-making processes (e.g., Dahl, 1961; Lowry, 1986). The nature of leadership in a community inevitably 
leads us to communication and how elites "discuss" significant issues in the public domain. The role of media also is important here because it is through newspaper coverage and broadcast news accounts that the public witnesses agenda-setting, as well as conflict, among influential citizens.

Efforts to strengthen democratic processes in urban centers could improve with the recognition that those representing "powerful" interests themselves are constrained, and that a model which recognizes the mutual dependence of participants in public debates could prove productive in generating research questions. In the Tichenor et al. (1980) model, media stress consensus and avoid conflict in more homogeneous communities. Here we are focusing on a metropolitan context with the diversity that accompanies large populations; thus, conflict is to be expected as different interests struggle to succeed in representing their interests. The pluralism perspective and models of community power tend to be static in their assumptions. To this mix, we can add the enduring spiral of silence literature, which suggests that perceived climate affects one's willingness to speak out in public. This theory speaks to the general public, but clearly elites, who are highly visible when they contribute to the public dialogue and also must take into account the climate for communication.

Here, we ask how elites view the public sphere from their vantage point, which includes the public forums and media to which we all have access, but which they can compare with private conversations and access to information about local problems not available to the general public. Savage and Williams (2008) argued that elites have been forgotten by the social sciences, and called for empirical investigations of their composition and the differences they make. Engelstad (2009) noted that elites are regulated not only by specific institutional requirements, but also by the public sphere, so it is important for us to examine their perceptions of public discourse. Thus, we examine several aspects of the nature of communication about significant issues in the public sphere by influentials and the general public: (a) the fluidity of influentials in democratic practice at the community level, (b) comparisons of influentials and the general public on community assessments, (c) views of influentials about discussion in the public arena, and (d) public views of the climate for discussing opinions in public.

\section{Influentials' Tenure in the Public Sphere}

The fluidity of influentials in roles of power certainly differs by level and political system. Here, we apply the pluralistic model to Cleveland, Ohio. At three different points - in 1982, 1993, and 2005-in-person interviews were conducted with small samples of influentials (35 interviewed in 1982; 25 in 1993; and 15 in 2005) identified by position/status and reputation across different domains. The purpose of each set of interviews was unique - the first focusing on community image and credibility, the second on the perceived quality of life, and the third on public discussion of community issues.

Identifying influentials can follow several paths. The actual spheres of influence, or domains where power is based, are identified through careful observation by the researchers and knowledgeable observers. Lists also are available representing important 
interests in the community; for all private and some public sectors (e.g., industry, finance, and foundations-associations), the business newspaper covering the metropolitan area compiles lists ranking units by size or magnitude. These lists nominate candidates for influence within their respective domains. For the 1982 interviews with influentials, reporters and other knowledgeable observers were asked to rank, in terms of importance, individuals of influence within their areas of expertise. ${ }^{3}$ In 1993, similar methods were followed, but some changes in areas/domains were necessary to reflect what were perceived as shifts in the significance of various areas to the economy and public life. ${ }^{4}$ More than one decade later, in the spring of 2005, interviews were conducted with another set of influentials following the same procedures. These procedures are similar to those followed in other studies of elites (Yamokoski, 2008).

Reviewing the candidates and individuals interviewed across the three time periods, we are struck by the almost complete turnover of those in power. In identifying the areas for influence across more than two decades, some decline while others emerge-recognition that the economy changed and the topics of discussion and issues decided changed with the times as well (e.g., manufacturing and industry declined while health grew in importance). In 1982, basic economic issues stemming from shifts in industry spilled into the political arena; in 1993, the mayor was publicly discussing efforts to lure the professional football team away from town; and in 2005, the mayor and city council president-soon to be locked in a political battle for mayor-conflicted in public over support for a center-city shopping center with the anti-union Wal-Mart as the lead tenant. The three lists of influentials contained almost no overlapping names as new officials were elected, chief executive officers moved, and prominent figures retired to be replaced by new faces. This supports a dynamic pluralistic model of power. Comparisons of perceptions by the general public and by influentials also are available for 1982, 1993, and 2005, although the focus was different.

\section{Influentials Versus Public Views of Significant Issues}

Comparisons of influentials with the general public are available drawing on data from surveys conducted parallel to interviews of influentials. In 1982, Cleveland suffered from years of jokes that had tarnished its image and created considerable consternation among residents and leaders alike. ${ }^{5}$ A public survey conducted at the same time as the in-person interviews with influentials contained an identical measure of the perceived quality of life in the metro area. A comparison shows that elites are more sensitive to negative media images of the city, supporting the notion of the watchdog function of the press. ${ }^{6}$ Clearly, influentials have more personal resources and live in more affluent neighborhoods, making the physical aspects of the quality of life more attractive, but leaders and the public alike blame the media for presenting a distorted image of the larger community. In 1993, both the general public and influentials gave positive assessments of the quality of life in the area, but a similar assessment gap remained despite improved images. ${ }^{7}$ One decade after giving both the external image and media negative marks, influentials saw a vast improvement 
in the area's image and a commensurately more positive assessment of the media. ${ }^{8}$ One influential said, "Cleveland is still a fairly well-kept secret, but the rest of the country is beginning to learn how great Cleveland is." Another influential said his assessment had dramatically improved because "the word is getting out about the real Cleveland." A third noted that, despite "bad media coverage, Cleveland's revitalization is impressive to outsiders."

In 2005, as the city approached a mayoral election, public debates centered around a continuing economic decline and whether leaders had a vision for the area's future. Housing was popping up throughout city neighborhoods, where almost no new housing was seen 2 decades earlier, but retail in the city declined as urban sprawl pulled people to outlying areas and the economy continued to sputter. ${ }^{9}$ The general public rated the quality of life in the metro area slightly lower than 1 decade earlier. They also gave the media a fair-to-middling rating for their coverage of the local community. ${ }^{10}$ Thus, the public seemed to reflect the malaise frequently cited in the media. The most recent data focused more on the quality of discussion in the public sphere, and several items tapped political efficacy and perceptions of public interaction and conflict. Clearly, the general public feels somewhat powerless, with

only one-half giving positive assessments. ${ }^{11}$ Substantial percentages are critical of both fellow citizens and the quality of public communication. Using in-person interviews, we ascertained whether influentials share these perceptions. Because conflict is a characteristic feature of communication in a pluralistic system, we might expect a different view of public debates by elites.

\section{Influentials' Assessment of Communication in the Public Arena}

In a democracy, public discussion of significant issues requires that political leaders and other influential persons debate the pros and cons of various problems, encourage problem solving, and offer solutions to problems that are the subject of both public and private forums. What influential members of the community say in "public" also should be covered by the media so that voters can judge their actions and opinions and influence policymakers.

Today, some fear that the public sphere has become overwhelmed by popular culture and a disinterested public. Leaders follow, rather than lead. They allow themselves to "spin," rather than articulate, plausible solutions to real problems; and, although media channels have multiplied, attention to serious public discussion has not. Interviews conducted in the spring of 2005 sought to understand the views of community influentials, which have a unique vantage point to observe public debates, even when they are not contributing to the dialogue. How do they view the public discussion in Cleveland today, and what can we learn about the climate for communication about significant issues? Local observers claimed there was a spiral of silence among business leaders (Miller, 2005) and that civic space, where open conversations regarding civic issues take place, was disappearing. The concept of the public sphere is a useful tool for explaining social change, as well as other complex social and communication processes, in present-day democracies (Pinter, 2004). ${ }^{12}$ 
Research questions posed for the 2005 interviews of influentials were as follows:

RQ1: Will persons who hold positions of influence in the community of greater Cleveland identify the same issues as significant problems?

RQ2: How do influentials assess the quality of public communication and its outcome for problem solving?

RQ3: How do influentials judge the performance of media?

The mass media are the primary source of information about the community not only for the general public, but also influentials. Although elites have access to information to which the general public is not privy, this access is limited to particular domains, and does not extend across all areas of potential conflict. ${ }^{13}$

Influentials generally agreed on the key problems in the community, with all 15 identifying economic problems as the central issue facing greater Cleveland. A key influencial in the nonprofit sector said, "The greatest problem is economic competitiveness and all the related issues, quality of education, taxation, fragmented government." Whereas some named the economy specifically, others referred to job losses or economic status as buzz words for the same concept. The theme of economic problems emerged in the initial minutes of each interview. Fourteen of the 15 interviewees had cited education as the other major problem for greater Cleveland. A majority also saw the issues of jobs, and job creation, as a problem closely allied to the problems of education. Although education was cited as a broad concept, few made references to specific school districts outside the urban core. No one offered solutions, such as solving school funding problems. They saw jobs and education as going hand in hand because of the importance of having a skilled, educated workforce. In general, it looks as if there is considerable consensus on the problems facing the community, perhaps an indication that the agenda-setting function of the media operates for both elites and the general public.

Influentials also assessed the quality of public communication. Whereas some leaders felt that there was sufficient discussion of issues in both private and public forums, others disagreed. However, whether these leaders thought there was sufficient or insufficient discussion of community problems, a major theme became apparent: Discussion, whether in the public or private sphere, did not give rise to solutions. A corporate vice president said, "I'd like to see more conversations that lead to solutions, not just complaints with no actions to follow. Teachers, for example, we want them to be highly qualified but pay them very little and consider them low on the social, professional totem pole." A political figure said, "[A] multitude of organizations are trying to tackle these problems but discussions have not resulted in any solutions." One of the media/promotional communication influentials strongly emphasized the lack of problem solving in discussions. He asserted that that local media devoted an entire evening of prime-time broadcasting fundraising for Tsunami relief, but failed to place a similar emphasis on problem solving for Cleveland public schools. Similarly, a county-elected official pointed out that people put bumper stickers on their cars for national issues such as Terry Schiavo and the war in Iraq and go to public forums about the efficacy of gay marriage, but ignore local problems that directly impact their lives. Thus, elites express frustration likely 
felt by the general public in creating a sense of urgency for a problem such as education, but they did not advance any solutions or suggest that the media or public were ignoring potential solutions. This reflects the media's tendency to move on to other issues, with a short attention span for any single issue. Although we could argue that this illustrates a deficiency in the "ideal speech situation," it also may reflect that the elites have not developed a consensus about how to solve the problem or that solutions, in part, are found outside the area-in particular, the state of Ohio's funding of public schools and the legislature's refusal to respond to the courts. To be fair, at least one commentator in the media blamed a lack of leadership for the neglect of education.

When asked whether there were problems not discussed in the public arena, the influentials identified several, but racial relations/racism was the most frequently cited. One major public official said, "Race is no longer discussed. Urban development is no longer discussed. People of wealth and influence have written off the poor. The parents or single parent of kids in Cleveland schools have no political clout." Racial relations also are the topic often found to illustrate the spiral of silence (e.g., Jeffres, Neuendorf, \& Atkin, 1999). Four of those interviewed avoided the question by giving nonresponsive answers, but five of the 15 responded that race or racism was a problem in the community that was not discussed in public forums. Other examples of problems not discussed were gay rights issues, AIDS and sexually transmitted diseases, the environment, and public safety. "There is very little or no discussion about drug issues because there is little interest in rehabilitating prisoners," said a judge. "We put them in prison and forget about them. As long as they are there, it's fine. Communities do not have forums for discussing re-entry problems."

Neither the media nor public officials fared well for their frankness and overall credibility and candor. "All media are selective, and they have their own individual prejudices," said a cultural influencial. A majority of the influentials interviewed believe that public officials do not reveal their true feelings for fear of retribution. Elected officials were targeted as being concerned about getting reelected or feared raising issues that would endanger their relationship with financial backers and voters. Only the judge voiced the opinion that community leaders did reveal their true opinions. One public official said that public leaders often temper their responses based on the audience, telling the public what they want to hear.

Likewise, the media were seen as highly selective in their coverage of public issues and debates, with an emphasis on ratings and tabloid news. Those interviewed said issues are discussed in an episodic format, which leads to a lack of continuity in public debate. When the story is hot, it is covered; then, it moves to the back page or out of the picture. One influencial said, "[T]he media operate with a crisis mentality." Although there was talk of the expanding range of alternatives for the obtaining of news, the majority agreed that most people continue to get most news coverage from television and, to a lesser extent, the metropolitan daily, although the print media are recognized as providing more in-depth coverage.

One question asked if there are sufficient areas in the public sphere, such as community meetings and public forums, for problems to be aired. Several themes 
emerged. A religious leader said there are more than enough forums, but decision makers who could provide solutions are stretched too thin and do not attend them. A media influential saw these meetings as formalities, where people talk, but nothing gets done. A business leader cited the venerable City Club as a significant forum for debate. However, both the media influential and the business leader echoed the opinions of others influentials, who bemoaned the lack of coverage for such structured forums of debate. They said that rebels and protestors get coverage at the expense of legitimate debate. As leaders, influentials were asked if people came to them privately about community problems they thought were not getting enough attention in the public sphere. The director of a foundation and a media influential said that people came to them with community problems on a regular basis. This was not the case with other influentials. There appears to be a deficiency in the pluralism model; the media in a diverse metropolitan area such as Cleveland may cover conflict because it is functional, but there is no guarantee that recognition of the problem will be followed by coverage of potential solutions or political leaders and other elites will develop a consensus on solutions.

\section{Summary and Discussion}

Despite a changing of the guard among leaders across domains, they continue to rate the quality of life in the community higher than the general public, and they see a continuing improvement over the decades. Although the public and elites blame the media for a poor image in 1982, by 1993, influentials see an improvement and give the media higher marks. Most recently, the general public and influentials alike provide a critical view of public discussion concerning local issues and bemoan the inability of public dialogue to generate solutions. The influentials seem to agree with the premise set forth by Miller (2005) that leadership in this pluralistic community has failed to engage in productive dialogue leading to problem solving. Although we would temper any notion there is a conspiracy of silence among greater Cleveland influentials, we do concur with some of those interviewed that leaders, too, "fear" retribution for expressing their views in the public sphere concerning significant community problems.

On the other hand, the research reveals that influentials agree in identifying the key problems facing the community. They criticize the media for failing to cover substantive debates in the public and private forums available in the community. As with most research questions, the end result is another question. If influentials face the same inhibitions as the general public in a spiral of silence, what would improve the climate for substantive problem-solving discussions?; and, How can the media be convinced they have a crucial role in not only setting the agenda, but advancing the dialogue?

Changing the way media cover community problems is an ambitious task, but further fragmentation of the media audience into smaller and smaller niches is likely to be a more important issue. This fragmentation also leads to less and less common exposure to the same messages, with the public - and perhaps elites - spending more 
time listening to people with whom they agree than to "other sides." A pessimist might conclude that things will inevitably get worse with this scenario, but the same media fragmentation also shifts increasing control to audiences, where the elite access to powerful media may be cancelled by individuals with "authoritative voices" and, perhaps, a following willing to embrace their views and challenge the established channels. As traditional media institutions lose some of their influence with the growth of communication technologies that shift control to "small" voices via blogs and other channels, we may come closer to a "public sphere" that is more chaotic, but also likely to fit Habermas's (1990) "ideal speech situation," where anyone can comment and criticize proposals. However, problem solving also requires leadership by "elites," and the question is whether this changing communication environment will be matched by political structures and processes that respond to the moment.

\section{Notes}

[1] See Scott (2008) for a thorough examination of the concept of power and conceptualization of elites.

[2] For a recent review of 50 years of power structure research, see Domhoff (2007).

[3] Areas and the number of completed interviews were law and justice (2), foundationsassociations (2), media (3), education (4), arts-entertainment-leisure (5), finance (2), business-retail (4), health (3), industry and labor (5), politics and government (4), and religion (1). In-person interviews were conducted with these 35 influentials.

[4] The survey netted the following set of completed interviews by area: arts and entertainment (3), business-retail (2), education (3), foundations-associations (2), finance and law (2), health (3), industry (1), labor (1), media (3), politics and government (2), and religion and ethics (2). Similarly, in 2005, in-person interviews were completed for the following areas: law and justice (2), industry (1), business-retail (1), media (2), foundationsassociations (1), religion and ethics (2), arts-entertainment (1), and politics and government (2). The methodology for the 1982 and 1993 surveys of influentials is described in Jeffres, Jian, Lee, Connally, and El Seikali (1993).

[5] See Adler (1982).

[6] Using a 0 to 10 scale, where 0 was the worst place to live and 10 the best, the general public gave an average rating of $6.39(N=439)$, reflecting the negative image, whereas influentials offered a much higher $7.85(t=7.08, p<.01)$. When asked whether the media presented an accurate picture of the quality of life in Cleveland, $50 \%$ of the general public thought the media distorted the city's image and were responsible for a bad reputation, whereas $74 \%$ of influentials gave media the same negative marks $(z=2.70, p<.05)$.

[7] Influentials rated the area 8.29 on the 0 to 10 scale, whereas the general public rated it 6.44 $(N=320)$. Between 1982 and 1993, many jobs had been lost, but the city had rebounded with an active entertainment district and improvements in other areas. Influentials were asked how accurate they thought the media's image of the area was, and $66.5 \%$ said it was very or somewhat accurate, whereas $29 \%$ said it was somewhat or very inaccurate.

[8] See "National Image of Cleveland Is Changing; City Now Viewed as Great Destination" (PR Newswire, January 2, 1992).

[9] See Larkin (2005) and Ott and Breckenridge (2006) for commentary on this time period.

[10] The score was 5.30 on a 0 to 10 scale for a sample of 144 people.

[11] Three statements measuring efficacy were introduced, and respondents were asked how much they agreed with each on a 0 to 10 scale, where 0 means they completely disagreed and 10 means they completely agreed ( 5 was neutral). The items and their means are as 
follows: "Public officials don't care much what people like me think" (5.08), "Other than voting, people like me have little influence over local government actions" (4.13), and "People like me don't have any say about what the government does" (4.26). Clearly, the general public feels somewhat powerless, with only one-half giving positive responses to any of the items. Five other statements reflect the public's assessment of public interaction, problem solving, and conflict in the community; again, respondents used the same 0 to 10 scale, where 0 means they completely disagreed and 10 means they completely agreed. The first two statements and means focus on communication: "People in this community seem to be afraid to speak up when they disagree" (4.16), and "No one seems shy about disagreeing with neighbors or public officials in my community" (5.60). Three additional statements focus on problem solving and conflict: "People don't work together to get things done for my community" (5.46), "People in this community deal fairly and squarely with each other" (4.78), and "There's a lot of conflict among people in my community" (5.07). Responses hover around the mean on each of these communication items.

[12] Also see Jacobson and Storey (2004), Kincaid (2000), Storey, Boulay, Karki, Heckert and Karmacha (1999), and Valente and Saba (1998). Special interest publics, social movements, and environmental groups face a number of obstacles in terms of their access to the media and to the control of their image (Delicath \& Deluca, 2003).

[13] Contact the authors for a schedule of questions guiding interviewers. Influentials were interviewed in the following areas: labor, foundations, law and justice, religion and ethics, politics and government, education, health, arts and entertainment, industry, business and retail, the media, and law and finance.

\section{References}

Adler, A. (1982, December 12). Outfit is unfunny joke to city. Associated Press, PM Cycle.

Dahl, R. A. (1961). Who governs?: Democracy and power in an American city. New Haven, CT: Yale University Press.

Delicath, J. W. \& Deluca, K. M. (2003). Image events, the public sphere, and argumentative practice: The case of radical environmental groups. Argumentation, 17, 315-333.

Domhoff, G. W. (2007). C. Wright Mills, Floyd Hunter, and 50 years of power structure research. Michigan Sociological Review, 21, 1-54.

Engelstad, F. (2009). Democratic elitism-Conflict and consensus. Comparative Sociology, 8, 383-401.

Habermas, J. (1990). Moral consciousness and communicative action. Cambridge, MA: MIT Press.

Habermas, J. (1998). Learning by disaster? A diagnostic look back on the short 20th century. Constellations, 5, 307-320.

Jacobson, T. L. \& Storey, D. J. (2004). Development communication and participation: Applying Habermas to a case study of population programs in Nepal. Communication Theory, 14, 99-121.

Jeffres, L. W., Cutietta, C., Sekerka, L., \& Lee, J. (2000). Newspapers, pluralism and diversity in an urban context. Mass Communication \& Society, 3, 157-184.

Jeffres, L. W., Jian, G., Lee, J.-W., Connally, C. E., \& El Seikali, J. (1993). Sensitivity to media images: Influentials vs. general public. Unpublished manuscript.

Jeffres, L. W., Neuendorf, K. A., \& Atkin, D. (1999, April-June). Spirals of silence: Expressing opinions when the climate of opinion is unambiguous. Political Communication, 16, 115-131.

Kincaid, D. L. (2000). Mass media, ideation, and behavior: A longitudinal analysis of contraceptive change in the Philippines. Communication Research, 27, 723-763.

Larkin, B. (2005, November 9). Campbell never acclimated to her hometown. Plain Dealer, p. B19.

Lowry, D. T. (1986). Establishing construct validity of the Hayakawa-Lowry news bias categories. Journalism Quarterly, 63, 573-580. 
Lynd, R. S. \& Lynd, H. M. (1929). Middletown. New York, NY: Harcourt Brace.

Lynd, R. S. \& Lynd, H. M. (1937). Middletown in transition. New York, NY: Harcourt Brace.

Miller, J. (2005, April 11-15). Desire not to offend has become offensive. Crain's Cleveland Business, $26,10-11$.

Ott, T. \& Breckenridge, T. (2006, February 19). Cleveland struggling to believe in itself; past problems keep many stuck in negative mind-set, region's image boosters say. Plain Dealer, A1.

Pinter, A. (2004). Public sphere and history: Historians' response to Habermas on the "worth" of the past. Journal of Communication Inquiry, 28, 217-232.

Savage, M. \& Williams, K. (2008). Elites: Remembered in capitalism and forgotten by social sciences. Sociological Review Monograph, 56, 1-24.

Scott, J. (2007). Power, domination and stratification: Towards a conceptual synthesis. Sociologia, Problemas e Praticas, 55, 25-39.

Scott, J. (2008). Modes of power and the re-conceptualization of elites. Sociological Review Monograph, 56, 25-43.

Storey, D., Boulay, M., Karki, Y., Heckert, K., \& Karmacha, D. M. (1999). Impact of the integrated communication project in Nepal, 1994-1997. Journal of Health Communication, 4, 271-294.

Tichenor, P. J., Donohue, G. A., \& Olien, C. N. (1980). Community conflict and the press. Beverly Hills, CA: Sage.

Valente, T. W. \& Saba, W. P. (1998). Mass media and interpersonal influence in a reproductive health communication campaign in Bolivia. Communication Research, 25, 96-124.

Vidich, A. J. \& Bensman, J. (1960). Small town in mass society. New York, NY: Doubleday.

Wright Mills, C. (1956). The power elite. New York, NY: Oxford University Press.

Yamokoski, A. (2008). How do elites define influence? Personality and respect as sources of social power. Sociological Focus, 41, 319-336. 